ISSN : 2580-3220, E-ISSN : 2580-4588

J. Mandiri., Vol. 4, No. 2, Desember 2020 (178 - 191)

(c)2018 Lembaga Kajian Demokrasi

dan Pemberdayaan Masyarakat (LKD-PM)

DOI : https://doi.org/10.33753/mandiri.v4i2.116

\title{
Pengaruh Corporate Governance, Ukuran Perusahaan, dan Leverage Terhadap Earnings Management Dengan Variabel CSR Sebagai Variabel Intervening
}

\author{
Fitriyah \\ Fakultas Ekonomi, Universitas Pamulang \\ dosen02472@unpam.ac.id
}

\begin{abstract}
Abstrak
Penelitian ini bertujuan untuk menguji pengaruh corporate governance, ukuran perusahaan dan leverage terhadap earnings management dengan corporate social responsibility sebagai variabel intervening (Studi Empiris Pada Perusahaan Manufaktur Yang Terdaftar di Bursa Efek Indonesia Tahun 2015-2018). Populasi dalam penelitian ini sebanyak 143 perusahaan. Teknik sampel yang digunakan adalah Purposive Sampling dan jumlah sampel 30 perusahaan. Model yang digunakan dalam penelitian ini adalah regresi logistik menggunakan aplikasi Eviews 8.0. Hasil penelitian : ukuran dewan komisaris berpengaruh negatif namun tidak signifikan terhadap corporate social responsibility. dewan komisaris independen berpengaruh positif namun tidak signifikan terhadap corporate social responsibility. komite audit, ukuran perusahaan dan leverage berpengaruh positif signifikan terhadap corporate social responsibility. ukuran dewan komisaris, dewan komisaris independen, dan komite audit berpengaruh negatif signifikan terhadap earnings management. Ukuran perusahaan, Leverage dan corporate social responsibility berpengaruh positif signifikan terhadap earnings management. ukuran dewan komisaris dan dewan komisaris independen secara signifikan tidak berpengaruh pada earnings management melalui corporate social responsibility. Hal ini menunjukan corporate social responsibility tidak dapat memediasi hubungan antara variabel ukuran dewan komisaris dan dewan komisaris independen dengan variabel earnings management. komite audit, ukuran perusahaan, dan leverage secara signifikan berpengaruh pada earnings management melalui corporate social responsibility. Hal ini menunjukan corporate social responsibility sebagai parsial mediator diantara variabel komite audit, ukuran perusahaan dan leverage dengan variabel earnings management.
\end{abstract}

Kata Kunci : Corporate Governance, Ukuran Perusahaan, Leverage, Corporate Social Responsibility, Earnings Management

\begin{abstract}
This study aimed to examined the effect of corporate governance, firmsize and leverage on earnings management through corporate social responsibility (empirical studies on Manufacturing Company listed on Indonesian Stock Exchange 2015-2018). The population in this study is 143 companies. The sample in this study by 30 companies using purposive sampling method. Data analysis used in this study is the logistic analysis by Eviews 8.0 program. The result indicate that: the board size had negatif not significant on corporate social responsibility, board of independent commissioners had positif not significant on corporte social responsibility. audit committee, firm size and leverage had positive significant effect on corporate social responsibility. the board size, board of independent commissioners and audit commitee had negatif significant effect on earnings management. Firm size, leverage and corporate social responsibility had positif significant effect on earnings managemet. The board size and board of independent commissioner by significant not effect on earnings management through corporate social responsibility. this indicates corporate social responsibility can not mediate the relationship
\end{abstract}


between variable the board size and board of indepedent commissioner with variable earnings management. audit commitee, firm size and leverage by significant effect on earnings management through corporate social responsibility. this indicates corporate social responsibility as a partial mediator between variable audit commitee, firm size and leverage with earnings management.

Keywords: Corporate Governance, Firm Size, Leverage, Corporate Social Responsibility, Earnings Management

\section{PENDAHULUAN}

Laporan keuangan merupakan ringkasan dari transaksi-transaksi keuangan yang terjadi selama tahun buku yang bersangkutan (Gunawan dkk, 2015). Selanjutnya, Pradnyani \& Sisdyani (2015) mengatakan bahwa salah satu tujuan pelaporan keuangan adalah memberikan informasi keuangan yang dapat menunjukkan prestasi perusahaan dalam menghasilkan laba (earning per share). Informasi keuangan yang dapat menunjukkan prestasi perusahaan dalam menghasilkan laba adalah laporan laba rugi. Laporan laba rugi adalah laporan yang mengukur keberhasilan operasi perusahaan selama periode tertentu.

Laporan laba rugi membandingkan pendapatan terhadap beban pengeluarannya untuk menentukan laba atau rugi bersih. Laporan laba rugi digunakan oleh para investor untuk melihat profitabilitas perusahaan dan memprediksi prospek perusahaan di masa yang akan datang. Akan tetapi, laba yang dihasilkan dalam laporan laba rugi seringkali dipengaruhi oleh metode akuntansi yang digunakan, sehingga laba yang tinggi belum tentu mencerminkan kas yang besar (Wiagustini, 2010).

Manajemen laba suatu proses yang disengaja, dengan batasan standar akuntansi keuangan untuk mengarahkan pelaporan laba pada tingkat tertentu. Manajemen laba merupakan suatu kondisi di mana manajemen melakukan intervensi dalam proses penyusunan laporan keuangan bagi pihak eksternal sehingga dapat menaikkan, meratakan, dan menurunkan laba (Wirakusuma,2016).

Corporate Social Responsibility (CSR) adalah suatu komitmen berkelanjutan oleh dunia usaha untuk bertindak etis dan memberikan kontribusi kepada pengembangan ekonomi dari komunitas setempat atau masyarakat luas, bersaman dengan peningkatan taraf hidup pekerja beserta keluarganya (Hadi, 2014).

Perusahaan besar akan mendapatkan tekanan politis, yaitu tekanan untuk melaksanakan aktivitas CSR. Dengan melakukan pengungkapan CSR maka perusahaaan dapat menghindari biaya yang lebih besar akibat tuntutan masyarakat sekitarnya. Perusahaan besar akan melakukan pengungkapan CSR untuk mendapatkan legitimasi dari para stakeholder yang ada di perusahaan (Gayatri,2016).

Menurut Ghozali (2013) dalam stakeholder theory, perusahaan tidak hanya melakukan kegiatan usaha untuk kepentingan perusahaan sendiri tetapi juga harus bermanfaat bagi para stakeholder yang ada di perusahaan.

Perusahaan yang memiliki tingkat leverage tinggi berarti sangat bergantung pada pinjaman luar untuk membiayai asetnya. Sedangkan perusahaan yang mempunyai tingkat leverage lebih rendah, lebih banyak membiayai asetnya dengan modal sendiri (Rofiqkoh dan Priyadi, 2016).

Perusahaan besar melakukan pengungkapan aktivitas CSR untuk mendapatkan legitimasi dan nilai positif dari masyarakat. Perusahaan yang bertanggung jawab secara sosial dan mengerahkan usaha dan sumber daya yang mereka miliki dalam memilih dan menerapkan praktik CSR untuk mendapatkan harapan etis para pemegang saham dan masyarakat sekitarnya, akan lebih membatasi praktik manajemen labanya sehingga dapat memberikan informasi keungan yang lebih transparan dan dapat diandalkan (Gayantri, 2016).

Pada penelitian ini, variabel yang digunakan yaitu ukuran dewan komisaris, komposisi dewan komisaris, komite audit, ukuran perusahaan, leverage, dan corporate social responsibility. Dari uraian yang telah dipaparkan di atas, maka peneliti memilih judul: "Pengaruh Corporate Governance, Ukuran Perusahaan, dan Leverage Terhadap Earnings Management Dengan Variabel CSR 
Sebagai Variabel Intervening".

\section{METODE}

Populasi dalam penelitian ini adalah perusahaan manufaktur yang terdaftar di Bursa Efek Indonesia untuk periode 2015-2018 dengan jumlah perusahaan sebanyak 143 . Sampel penelitian ini adalah perusahaan manufaktur yang terdaftar di Bursa Efek Indonesia, dipilih dengan menggunakan purposive sampling dengan kriteria yang terdiri dari a) perusahaan manufaktur yang terdaftar di Bursa Efek Indonesia dan mempublikasikan laporan tahunan selama periode 20152018, b) tidak mengalami delisting selama tahun 2015-2018, c) perusahaan telah melakukan IPO minimal tahun 2014, d) perusahaan manufaktur yang memiliki data lengkap terkait dengan variabel penelitian antara lain informasi mengenai ukuran dewan komisaris, dewan independen, komite audit, ukuran perusahaan, dan leverage, e) perusahaan manufaktur yang mempublikasikan laporan keuangan yang dinyatakan dalam mata uang rupiah. f) perusahaan yang tidak mengungkapkan pertanggungjawaban sosial pada sustainability report selama 2015-2018. Berdasarkan kriteria tersebut, maka diperoleh sampel sebanyak 30 perusahaan.

Dewan komisaris bertanggung jawab dan berwenang mengawasi tindakan manajemen, dan memberikan pendapat kepada manajemen jika dipandang perlu oleh dewan komisaris (Amelia dan Hernawati, 2017). Dalam penelitian ini ukuran dewan komisaris diukur dengan menggunakan indikator jumlah anggota dewan komisaris dalam suatu perusahaan.

\section{UDK = Jumlah Anggota Dewan Komisaris}

Dalam penelitian ini dewan komisaris independen diukur dengan persentase jumlah anggota dewan komisaris dengan jumlah total komisaris yang ada dalam susunan dewan komisaris perusahaan sampel (Mabrurah, 2017)

$\mathrm{DKI}=\frac{\mathrm{Jml} \text { Anggota Komisaris Independen }}{\text { Jumlah anggota Dewan Komisaris }} \times 100$

Komite audit mempunyai peran yang sangat penting dan strategis dalam hal memelihara kre- dibilitas proses penyusunan laporan keuangan seperti halnya menjaga terciptanya system pengawasan perusahaan yang memadai serta dilaksanakan good corporate governance ( Pradana, 2017). Dalam penelitian ini komite audit diukur dengan jumlah susunan komite audit berdasarkan pada data yang dicantumkan.

\section{KA = Jumlah Anggota Komite Audit}

Semakin besar rasio leverage akan menunjukkan semakin besar tingkat ketergantungan perusahaan terhadap kreditur dan semakin besar harus dibayar oleh perusahaan (Gunawan dkk, 2015). Dalam penelitian leverage diukur dengan menggunakan rasio total hutang terhadap total aset.

$$
\text { Leverage }=\frac{\text { Total Hutang }}{\text { Total Asset }}
$$

Manajemen laba yaitu suatu kemampuan untuk memanipulasi pilihan-pilihan yang tersedia dan mengambil pilihan yang tepat untuk dapat mencapai tingkat laba yang diinginkan (Suryani, 2015). Dalam penelitian ini, proxy manajemen laba yang digunakan adalah discretionary accrual yang dihitung dengan menggunakan model Jones yang dimodifikasi.

\section{DTACt $=($ TACt/TAt-1 $)-$ NDTACt}

Instrumen pengukuran Corporate Social Responsibility Index (CSRI) yang dipakai untuk penelitian ini berdasarkan pada instrumen yang telah digunakan oleh Urip (2014). Pemilihan instrumen yang digunakan oleh (Ricardo, 2015) dikarenakan instrumen pengukuran corporate social responsibility tersebut telah disesuaikan dengan masing-masing sektor industri yang ada. Rumus perhitungan CSRI yang digunakan berdasarkan Rice (2016):

$$
\operatorname{CSRI}=\frac{\sum x i j}{n j} \times 100 \%
$$

\section{HASIL dan PEMBAHASAAN}

Hasil

\section{Statistik Deskriptif}

Berdasarkan pengolahan data melalui software Eviews 8, diperoleh nilai minimum, maksimum, rata-rata, dan standar deviasi dari masing-masing variabel penelitian. Hal tersebut dapat dilihat pada tabel 1 berikut: 


\begin{tabular}{|c|c|c|c|c|c|c|c|}
\hline & UDK & DKI & KA & UP & LEVERAGE & CSR & MANLAB \\
\hline Mean & 3.925000 & 39.60242 & 3.141667 & 24.46308 & 0.512786 & 0.276923 & 0.042500 \\
\hline Median & 3.000000 & 33.33000 & 3.000000 & 26.34211 & 0.449625 & 0.269235 & 0.047376 \\
\hline Maximum & 8.000000 & 60.00000 & 5.000000 & 29.78083 & 2.660630 & 0.670330 & 0.459950 \\
\hline Minimum & 2.000000 & 25.00000 & 3.000000 & 14.43591 & 0.044500 & 0.076920 & -0.486080 \\
\hline Std. Dev. & 1.529335 & 9.154166 & 0.454591 & 4.331922 & 0.451559 & 0.139799 & 0.016099 \\
\hline Skewness & 0.721141 & 0.711702 & 3.252412 & -1.033965 & 3.072689 & 0.723782 & -0.687876 \\
\hline Kurtosis & 2.678850 & 2.286695 & 12.59487 & 2.793719 & 14.56949 & 2.835734 & 7.925191 \\
\hline Jarque-Bera & 10.91659 & 12.67440 & 671.8715 & 21.59442 & 858.0936 & 10.61212 & 130.7510 \\
\hline Probability & 0.004261 & 0.001769 & 0.000000 & 0.000020 & 0.000000 & 0.004961 & 0.000000 \\
\hline Sum & 471.0000 & 4752.290 & 377.0000 & 2935.569 & 61.53437 & 33.23080 & 5.099942 \\
\hline Sum Sq. Dev. & 278.3250 & 9972.051 & 24.59167 & 2233.100 & 24.26474 & 2.325705 & 1.603994 \\
\hline Observations & 120 & 120 & 120 & 120 & 120 & 120 & 120 \\
\hline
\end{tabular}

Berdasarkan tabel 1 hasil analisis dengan menggunakan statistik deskriptif terhadap ukuran dewan komisaris nilai minimum sebesar 2,00, nilai maksimum 8,00 dengan rata-rata sebesar 3,9250 dan standard deviasi sebesar 1,529335. Hasil analisis dewan komisaris independen (DKI) yang dihitung dengan persentase jumlah dewan komisaris independen terhadap jumlah seluruh komisaris menunjukkan nilai minimum sebesar 25,000, nilai maksimum 60,000 dengan rata-rata sebesar 39,4500 dan standar deviasi sebesar 9,264416. Hasil analisis komite audit (KA) yang dihitung dengan jumlah komite audit menunjukkan nilai minimum sebesar 3,000, nilai maksimum 5,000 dengan rata-rata sebesar 3,141667, dan standart deviasi 0,454591.

Selanjutnya hasil analisis ukuran perusahaan yang dihitung dengan logartima total aset menunjukkan nilai minimum sebesar 14,43591, nilai maksimum sebesar 29,78083 dengan nilai rata-rata sebesar 24,46308, dan standart deviasi sebesar 4,331992. Hasil analisis leverage yang dihitung dengan perbandingan antara total utang dan total aset menunjukkan nilai minimum sebesar 0.044500, nilai maksimum 2,660630 dengan rata-rata sebesar 0.512786 , dan standard deviasi sebesar 0.451559 . Hasil analisis corporate social responsibility menunjukkan nilai minimun sebesar 0.076920 , nilai maximum 0.670330 dengan nilai rata-rata sebesar 0.276923 dan standart deviasi sebesar 0.139799. Hasil analisis earnings mana- gement yang dihitung menggunakan nilai discretionary accrual menunjukkan nilai minimum sebesar -0.486080, nilai maksimum 0.459950 dengan rata-rata sebesar 0.042500 , dan standard deviasi sebesar 0.016099 .

Variabel ukuran dewan komisaris, dewan komisaris independen, komite audit, ukuran perusahaan, leverage, dan corporate social responsibility memiliki nilai rata-rata lebih besar dari nilai standard deviasi. Hal ini menunjukkan bahwa kualitas data dari variabel tersebut baik karena nilai rata-rata yang lebih besar dari nilai standar deviasinya, mengidentifikasikan bahwa standard error dari variabel tersebut kecil.

\section{Uji Normalitas}

Dilihat dari gambar 1 grafik terlihat bahwa nilai probability 0.004961 dari hasil tersebut dapat diartikan lebih kecil dari nilai signifikan yaitu 0.05 . Hal ini berarti data residul berdistribusi tidak normal.

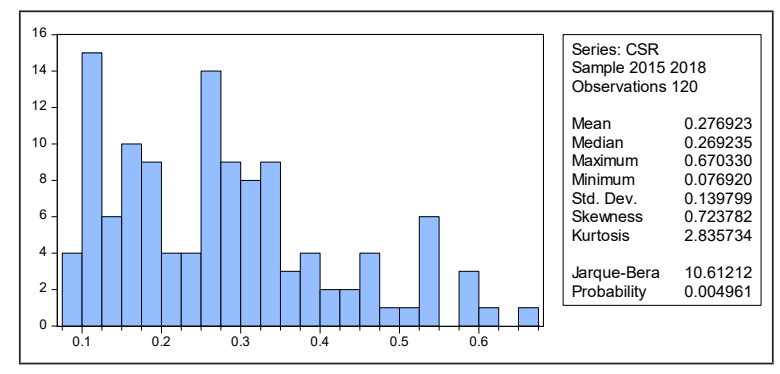

Gambar 1. Uji Normalitas 


\section{Uji Multikolinearitas}

Tabel2 menunjukkan bahwahasilperhitungan nilai Variance Inflation Factors (VIF) tidak ada satupun variabel independen yang memiliki nilai VIF lebih dari 10. Jadi dapat disimpulkan bahwa tidak terjadi multikolinearitas antar variabel independen dalam model penelitian ini.

\begin{tabular}{|c|c|c|c|}
\hline \multicolumn{4}{c}{ Tabel 2. Uji Multikolinearitas } \\
\hline \multirow{2}{*}{ Variable } & Coefficient & Uncentered & Centered \\
\cline { 2 - 4 } & Variance & VIF & VIF \\
\hline UDK & $9.18 \mathrm{E}-05$ & 10.78243 & 1.410917 \\
\hline DKI & $2.07 \mathrm{E}-06$ & 22.65113 & 1.139796 \\
\hline KA & 0.001059 & 70.67786 & 1.437623 \\
\hline UP & $1.06 \mathrm{E}-05$ & 43.27401 & 1.305067 \\
\hline LEVERAGE & 0.000842 & 2.595555 & 1.128304 \\
\hline C & 0.023756 & 157.3673 & NA \\
\hline
\end{tabular}

\section{Uji Heterokedastisitas}

Tabel 3 menunjukkan bahwa hasil hasil perhitungan uji heterokedastitas membuktikan nilai $\mathrm{Obs}^{\star} \mathrm{R}$-Squared mempunyai nilai prob. ChiSquare sebesar 0,0005 , hal ini berarti data nya bersifat homogen.

Tabel 3. Uji Heterokedastisitas

Heteroskedasticity Test: White

\begin{tabular}{|l|c|c|c|}
\hline F-statistic & 3.218698 & Prob. F(20,99) & 0.0001 \\
\hline Obs*R-squared & 47.28339 & Prob. Chi-Square(20) & 0.0005 \\
\hline Scaled explained SS & 44.40389 & Prob. Chi-Square(20) & 0.0013 \\
\hline
\end{tabular}

\section{Pemilihan Model Estimasi}

Tabel 4 Uji Chow menunjukkan bahwa nilai probabilitas pada F-test sebesar 1,00 dan nilai Chi-Square sebesar 1,00. Kedua nilai tersebut lebih besar dari 0,05 sehingga dapat disimpulkan bahwa model mengikuti Common Effect Model (CEM).

\begin{tabular}{|l|c|c|c|}
\hline \multicolumn{4}{c|}{ Tabel 4. Uji Chow } \\
\hline \multicolumn{1}{c|}{ Effects Test } & Statistic & d.f. & Prob. \\
\hline Cross-section F & 0.114082 & $(29,85)$ & 1.0000 \\
\hline Cross-section Chi-square & 4.582046 & 29 & 1.0000 \\
\hline
\end{tabular}

Tabel 5 Uji Housman menunjukkan bahwa nilai probabilitas pada nilai Chi-Square sebesar 0,6526. Nilai tersebut lebih besar dari 0,05 $\mathrm{se}^{-}$ hingga dapat disimpulkan bahwa menurut uji Hausman, model mengikuti Random Effect Model (REM).

\begin{tabular}{|c|c|c|c|}
\hline \multicolumn{4}{|c|}{ Tabel 5. Uji Housman } \\
\hline Test Summary & $\begin{array}{c}\text { Chi-Sq. } \\
\text { Statistic }\end{array}$ & Chi-Sq. d.f. & Prob. \\
\hline Cross-section random & 3.308377 & 5 & 0.6526 \\
\hline
\end{tabular}

Tabel 6 Langrange multiplier menunjukkan bahwa nilai probabilitas Breusch-Pagan sebesar 0,0000. Nilai tersebut lebih kecil dari 0,05, se hingga dapat disimpulkan bahwa model mengikuti Random Effect Model (REM).

\begin{tabular}{|c|c|c|c|}
\hline \multicolumn{4}{|c}{ Tabel 6. Langrange Multiplier } \\
$\begin{array}{c}\text { Null (no rand. effect) } \\
\text { Alternative }\end{array}$ & $\begin{array}{c}\text { Cross-section } \\
\text { One-sided }\end{array}$ & $\begin{array}{c}\text { Period } \\
\text { One-sided }\end{array}$ & Both \\
\hline \multirow{2}{*}{ Honda } & -4.344545 & 41.33032 & 26.15289 \\
\cline { 2 - 4 } & $(1.0000)$ & $(0.0000)$ & $(0.0000)$ \\
\hline \multirow{2}{*}{ King-Wu } & -4.344545 & 41.33032 & 38.01505 \\
\cline { 2 - 4 } & $(1.0000)$ & $(0.0000)$ & $(0.0000)$ \\
\hline \multirow{2}{*}{ SLM } & -4.072879 & 80.95678 & -- \\
\cline { 2 - 4 } & $(1.0000)$ & $(0.0000)$ & -- \\
\hline \multirow{2}{*}{ GHM } & -- & -- & 1708.195 \\
\cline { 2 - 4 } & -- & -- & $(0.0000)$ \\
\hline
\end{tabular}

Tabel 7 Kesimpulan dari uji pemilihan model seperti yang dijabarkan pada tabel bahwa model analisis regresi yang paling cocok untuk penelitian ini adalah Random Effect Model.

\begin{tabular}{|l|c|c|}
\hline \multicolumn{3}{c}{ Tabel 7. Kesimpulan Uji Pemilihan Model } \\
\hline \multicolumn{1}{c|}{ Jenis Uji } & Perbandingan Model & Model Terpilih \\
\hline Uji Chow & CEM vs FEM & FEM \\
\hline Uji Hausman & REM vs FEM & REM \\
\hline Uji Lagrange Multiplier & CEM vs REM & REM \\
\hline
\end{tabular}

Analisis regresi berganda. Tabel 8 hasil analisis regresi berganda menunjukkan bahwa nilai probabilitas ukuran dewan komisaris (UDK) terhadap corporate social responsibility adalah sebesar 0,3538 (>0,05). Hal ini berarti bahwa ukuran dewan komisaris berpengaruh dan tidak signifikan terhadap corporate social responsibility. Nilai probabilitas dewan komisaris independen (DKI) terhadap corporate social responsibility adalah sebesar 0,3941 (>0,05). Hal ini berarti dewan komisaris independen berpengaruh dan tidak signifikan terhadap corporate social responsibility.

Selanjutnya nilai probabilitas komite audit terhadap corporate social responsibility sebesar 0,0177 $(<0,05)$. Hal ini berarti komite audit berpengaruh terhadap corporate social responsibility. Nilai probabilitas ukuran perusahaan 
terhadap corporate social responsibility adalah sebesar 0,0030 $(<0.05)$. Hal ini berarti ukuran perusahaan berpengaruh terhadap corporate social responsibility. Nilai probabilitas leverage terhadap corporate social responsibility adalah sebesar 0,0219 (0,05). Hal ini berarti bahwa leverage berpengaruh terhadap corporate social responsibility.

\begin{tabular}{c|c|c|c|c|}
\hline \multicolumn{5}{|c}{ Tabel 8. Analisis Regresi Berganda } \\
\hline Variable & Coefficient & Std. Error & t-Statistic & Prob. \\
\hline UDK & -0.000124 & 0.002129 & -0.058097 & 0.3538 \\
\hline DKI & 0.000270 & 0.000316 & 0.855387 & 0.3941 \\
\hline KA & 0.002614 & 0.007212 & 2.362473 & 0.0177 \\
\hline UP & 0.486318 & 0.160135 & 3.036929 & 0.0030 \\
\hline LEVERAGE & 0.049102 & 0.499656 & 2.098272 & 0.0219 \\
\hline C & -10.21550 & 3.185933 & -3.206440 & 0.0017 \\
\hline
\end{tabular}

Tabel 9 Uji F (Anova) menunjukkan variabel UDK, DKI, KA, UP dan LVRG pada tabel regresi data panel menunjukkan nilai $\mathrm{f}_{\text {hitung }}$ sebesar 133,7088. Secara bersama-sama variabel independen memiliki nili prob (f-stat) 0,0000, di mana nilai tersebut lebih kecil dari 0.05 sehingga variabel independen secara bersama-sama memiliki pengaruh dan signifikan. Uji $\mathrm{F}$ ini dilakukan untuk mengetahui apakah variabel independen yang dimasukkan dalam uji regresi berganda memiliki pengaruh secara bersamasama atau tidak terhadap variabel dependen. Kemudian hasilnya digunakan untuk menguji apakah hipotesis diterima atau ditolak dengan membandingkan tingkat signifikan 0.05 (5\%). Kriteria pengujian adalah apabila nilai probability $\mathrm{F}$ lebih besar dari 0,05 , maka pengujian ini dilakukan dengan menggunakan program software eviews 8.0.

\begin{tabular}{|l|c|c|c|}
\hline \multicolumn{5}{|c}{ Tabel 9. Uji F } \\
\hline R-squared & 0.454321 & Mean dependent var & 0.340658 \\
\hline Adjusted R-squared & 0.347932 & S.D. dependent var & 0.070225 \\
\hline S.E. of regression & 0.027385 & Sum squared resid & 0.085492 \\
\hline F-statistic & 133.7088 & Durbin-Watson stat & 3.820814 \\
\hline Prob(F-statistic) & 0.000000 & & \\
\hline
\end{tabular}

\section{Pengujian Hipotesis}

Berdasarkan tabel 10 Analisis regresi logistik menunjukkan bahwa nilai probabilitas ukuran dewan komisaris terhadap earnings mana- gement sebesar 0,0407. Hal ini berarti ukuran dewan komisaris berpengaruh terhadap earnings management. Nilai probabilitas dewan komisaris independen terhadap earnings management sebesar 0,0479. Hal ini berarti komisaris independen berpengaruh terhadap earnings management. Nilai probabilitas komite audit terhadap earnings management sebesar 0,0277. Hal ini berarti komite audit berpengaruh terhadap earnings management.

Kemudian nilai probabilitas ukuran perusahaan terhadap earnings management besar 0,0426. Hal ini berarti ukuran perusahaan berpengaruh terhadap earnings management. Nilai probabilitas leverage terhadap earnings management sebesar 0.0052 . Hal ini berarti bahwa leverage berpengaruh terhadap earnings management. Nilai probabilitas corporate social responsibility terhadap earnings management sebesar 0,0263. Hal ini berarti corporate social responsibility berpengaruh terhadap earnings management dan secara bersama-sama diperoleh probabilitas sebesar 0.7390 .

\begin{tabular}{|c|c|c|c|c|}
\hline \multicolumn{5}{|c|}{ Tabel 10. Analisis Regresi Logistik } \\
\hline Variable & Coefficient & Std. Error & z-Statistic & Prob. \\
\hline UDK & -179.1714 & 264.9407 & -0.676270 & 0.0407 \\
\hline DKI & -4.900546 & 27.28155 & -0.179629 & 0.0479 \\
\hline KA & -120.2006 & 1321.523 & -0.090956 & 0.0277 \\
\hline UP & 0.005646 & 0.008192 & 0.689233 & 0.0426 \\
\hline LEVERAGE & 0.293099 & 0.102147 & 0.869390 & 0.0052 \\
\hline CSR & 0.139166 & 0.174094 & 0.799370 & 0.0263 \\
\hline C & -1570.358 & 4697.790 & -0.334276 & 0.7390 \\
\hline
\end{tabular}

\section{Pembahasan}

Berdasarkan pengujian regresi berganda dan regresi logistik sebagaimana telah dijelaskan pada bagian sebelumnya, interpretasi hasil disajikan dalam 16 bagian. Penjelasan enam belas bagian tersebut adalah sebagai berikut:

\section{Pengaruh Ukuran Dewan Komisaris (UDK) terhadap CSR}

Berdasarkan Tabel 8 menunjukkan koefisien regresi negatif sebesar -0,000124. Probabilitas menunjukkan nilai yang lebih besar dari 0,05 yaitu 0,3538 . Hal ini berarti tingkat signifikansinya lebih besar dari $\alpha=5 \%$, sehingga hipotesis ke-1 tidak didukung atau $\mathrm{H}_{0}$ diterima. Hasil penelitian 
ini ukuran dewan komisaris berpengaruh negatif dan tidak signifikan terhadap pengungkapan corporate social responsibility.

Hasil penelitian ini mendukung penelitian Herawati (2015) yang menyatakan bahwa banyaknya jumlah anggota dewan komisaris dalam perusahaan tidak serta merta membuat pengungkapan CSR lebih luas. Hal ini dikarenakan anggota dewan komisaris yang mempunyai tugas mengontrol pengendalian internal perusahaan dan pengawasan tidak hanya diukur berdasarkan jumlah anggota Dewan Komisaris melainkan lebih menitikberatkan pada nilai dan kepercayaan yang diterima dalam perusahaan serta kemampuan dan integritas anggota dewan komisaris. Sebaliknya, hasil penelitian ini tidak sejalan dengan penelitian yang dilakukan oleh Pradnyani \& Sisdyani (2015) yang menyatakan bahwa ukuran dewan komisaris berpengaruh terhadap pengungkapan CSR.

\section{Pengaruh Dewan Komisaris Independen (DKI) terhadap CSR}

Berdasarkan tabel 8 menunjukkan koefisien regresi positif sebesar 0,000270 . Probabilitas menunjukkan nilai yang lebih besar dari 0,05 yaitu 0,3941 . Hal ini berarti tingkat signifikansinya lebih besar dari $\alpha=5 \%$, sehingga hipotesis ke-2 tidak didukung atau $\mathrm{H}_{0}$ diterima. Hasil penelitian ini mendukung penelitian dari Susilo dan Mildawati (2015) bahwa dewan komisaris independen belum mampu memberikan rekomendasi agar manajemen menjalankan aktivitas sesuai dengan apa yang diinginkan para stakeholder, yaitu terkait pelaksanaan tanggung jawab sosial dan lingkungan yang berlandaskan pada prinsip-prinsip syariah. Selain itu besarnya proporsi dewan komisaris independen tidak meningkatkan atau mendorong perusahaan untuk melakukan pengungkapan corporate social responsibility. Sebaliknya penelitian ini tidak mendukung penelitian dari Wiyuda dan Purnomo (2017) yang menyatakan dewan komisaris berpengaruh terhadap luas pengungkapan corporate social responsibility.

\section{Pengaruh Komite Audit terhadap CSR}

Berdasarkan tabel 8 menunjukkan koefisien regresi positif sebesar 0,002614. Probabilitas menunjukkan nilai yang lebih kecil dari 0,05 yaitu 0,0177 . Hal ini berarti tingkat signifikansinya lebih kecil dari $\alpha=5 \%$, sehingga hipotesis ke-3 berhasil didukung atau $\mathrm{H}_{0}$ ditolak. Penelitian ini menunjukkan bahwa komite audit berpengaruh positif dan signifikan terhadap corporate social responsibility. Hasil penelitian ini mendukung penelitian dari Wiyuda (2017) bahwa semakin sedikit jumlah anggota komite audit akan semakin efektif dalam pengawasan terhadap laporan keuangan berkaitan dengan luas pengungkapan corporate social responsibility. Sebaliknya penelitian ini tidak mendukung penelitian yang dilakukan oleh Ginting (2016), Sukasih, dan Sugiyanto (2017) yang menyatakan bahwa komite audit tidak berpengaruh terhadap pengungkapan corporate social responsibility.

\section{Pengaruh Ukuran Perusahaan (UP) terhadap CSR}

Berdasarkan tabel 8 menunjukkan koefisien regresi positif sebesar 0,486318 . Probabilitas menunjukkan nilai yang lebih kecil dari 0,05 yaitu 0,0030. Hal ini berarti bahwa tingkat signifikansinya lebih kecil dari $\alpha=5 \%$, sehingga hipotesis ke- 4 berhasil didukung atau $\mathrm{H}_{0}$ ditolak. Penelitian ini menunjukan bahwa ukuran perusahaan berpengaruh positif dan signifikan terhadap corporate social responsibility. Hasil penelitian ini mendukung penelitian (Rofiqkoh \& Priyadi 2016 yang menyatakan bahwa ukuran perusahaan berpengaruh terhadap pengungkapan CSR menunjukkan bahwa kenaikan size yang diikuti dengan kenaikan corporate social responsibility yang berarti semakin besar ukuran perusahaan, maka semakin luas dalam mengungkapkan corporate social responsibility.

Perusahaan yang lebih besar mungkin akan memiliki pemegang saham yang memperhatikan program sosial yang dibuat perusahaan dalam laporan tahunan, yang merupakan media untuk menyebarkan informasi tetang tanggung jawab sosial perusahaan. Sebaliknya penelitian ini tidak mendukung penelitian yang dilakukan oleh Rindawati dan Asyik (2015), Pradnyani, dan Sisdyani (2015). Dalam penelitiannya menyatakan besar kecilnya ukuran perusahaan tidak 
mempengaruhi luas pengungkapan CSR. Hal ini disebabkan dengan adanya peraturan yang mewajibkan setiap perusahaan untuk mengungkapkan kegiatan CSR perusahaannya.

\section{Pengaruh Leverage terhadap CSR}

Berdasarkan tabel 8 menunjukkan koefisien regresi positif sebesar 0,049102 . Probabilitas menunjukkan nilai yang lebih kecil dari 0,05 yaitu 0,0219 . Hal ini berarti tingkat signifikansinya lebih kecil dari $\alpha=5 \%$, sehingga hipotesis ke-5 berhasil didukung atau $\mathrm{H}_{0}$ ditolak. Penelitian ini menunjukkan bahwa leverage berpengaruh positif dan signifikan terhadap corporate social responsibility.

Hasil penelitian ini mendukung penelitian Sumaryono dan Asyik (2017) di mana perusahaan dengan tingkat leverage yang tinggi mempunyai kewajiban yang lebih untuk melakukan pengungkapan corporate social responsibility. Ketika hutang perusahaan semakin naik sampai pada titik optimalnya, yang berarti bahwa perusahaan tersebut memiliki hutang yang semakin besar kepada kreditur. Agar perusahaan tetap diberikan pinjaman dan dipercaya oleh kreditur, maka dari itu perusahaan dengan tingkat rasio leverage yang tinggi akan melakukan pengungkapan corporate social responsibility. Sebagai bukti bahwa perusahaan tidak sedang dalam kondisi kebangkrutan sehingga kreditur mau untuk memberikan pinjamannya. Hasil penelitian ini tidak mendukung penelitian Elvina (2016) yang menyatakan leverage tidak berpengaruh terhadap corporate social responsibility.

\section{Pengaruh Ukuran Dewan Komisaris terhadap Earnings Management}

Berdasarkan tabel 10 menunjukkan koefisien regresi negatif sebesar -179,1714. Probabilitas menunjukkan nilai yang lebih kecil dari 0,05 yaitu 0,0407 . Hal ini berarti bahwa tingkat signifikansinya lebih kecil dari $\alpha=5 \%$, sehingga hipotesis ke-6 berhasil didukung atau $\mathrm{H}_{0}$ ditolak. Penelitian ini berhasil membuktikan bahwa ukuran dewan komisaris berpengaruh negatif dan signifikan terhadap earnings management.

Dari hasil ini menunjukkan jumlah dewan komisaris dapat menekan perilaku manajemen laba. Hal ini di duga semakin besar ukuran dewan komisaris maka semakin oprimal dalam pengawasan tindakan manajemen laba. Penelitian ini mendukung penelitian Mabrurah, Islahuddin, dan Arfan (2017) bahwa semakin sedikit dewan komisaris maka tindak manajemen laba makin banyak karena sedikitnya dewan komisaris memungkinkan bagi organisasi tersebut untuk didominasi oleh pihak manajemen dalam menjalankan perannya.

\section{Pengaruh Dewan Komisaris Independen terhadap Earnings Management}

Berdasarkan tabel 10 menunjukkan koefisien regresi negatif sebesar $-4,900546$. Probabilitas menunjukkan nilai yang lebih kecil dari 0,05 yaitu 0,0479 . Hal ini berarti tingkat signifikansinya lebih kecil dari $\alpha=5 \%$, sehingga hipotesis ke-7 berhasil didukung atau $\mathrm{H}_{0}$ ditolak. Penelitian ini berhasil membuktikan bahwa dewan komisaris independen berpengaruh negatif dan signifikan terhadap earnings management. Hal ini menunjukkan fungsi monitoring dewan komisaris independen sudah berjalan baik sehingga tindakan manajemen laba dapat dihindari. Penelitian ini tidak mendukung penelitian Savitri dan Priantinah (2019), dan Mabrurah, Islahuddin, dan Arfan (2017) bahwa dewan komisaris independen tidak berpengaruh terhadap manajemen laba.

\section{Pengaruh Komite Audit \\ terhadap Earnings Management}

Berdasarkan tabel 10 menunjukkan koefisien regresi negatif sebesar -120,2006. Probabilitas menunjukkan nilai yang lebih kecil dari 0,05 yaitu 0,0277 . Hal ini berarti bahwa tingkat signifikansinya lebih kecil dari $\alpha=5 \%$, sehingga hipotesis ke-8 berhasil didukung atau $\mathrm{H}_{0}$ ditolak. Penelitian ini berhasil membuktikan bahwa komite audit berpengaruh negatif dan signifikan terhadap earnings management.

Penelitian ini mendukung penelitian yang dilakukan oleh Oktariyani (2015), yang menyatakan keberadaan komite audit perusahaan berhasil dalam mengurangi praktik manajemen laba. Namun penelitian ini tidak mendukung penelitian 
yang dilakukan Gunawan dan Situmorang (2016), yang menyatakan bahwa pengangkatan komite audit oleh perusahaan hanya dilakukan untuk pemenuhan regulasi, tetapi tidak dimaksudkan untuk menegakkan good corporate governance di perusahaan.

\section{Pengaruh Ukuran Perusahaan terhadap Earnings Management}

Berdasarkan tabel 10 menunjukkan koefisien regresi positif sebesar 0,005646 . Probabilitas menunjukkan nilai yang lebih kecil dari 0,05 yaitu 0,0426 . Hal ini berarti bahwa tingkat signifikansinya lebih kecil dari $\alpha=5 \%$, sehingga hipotesis ke-9 berhasil didukung atau $\mathrm{H}_{0}$ ditolak. Penelitian ini menunjukkan bahwa ukuran perusahaan berpengaruh positif dan signifikan terhadap earnings management. Kondisi ini menggambarkan bahwa peningkatan ukuran perusahaan akan menyebabkan terjadinya penurunan manajemen laba. Basis pemegang kepentingan yang dimiliki oleh perusahaan yang berukuran besar akan lebih luas sehingga kebijakan-kebijakan yang dilakukan akan berdampak besar bagi kepentingan masyarakat luas daripada perusahaan kecil. Perusahaan besar memiliki kecenderungan untuk meminimalisir praktik manajemen labanya. Hal ini terjadi karena pemegang saham dan pihak luar diperusahaan besar dianggap lebih kritis dibandingkan dengan perusahaan kecil sehingga tekanan yang lebih besar akan dihadapi perusahaan besar untuk menyajikan laporan keuangan yang lebih akurat.

Hasil penelitian ini mendukung Amelia dan Hernawati (2016) bahwa ukuran perusahaan baik kecil maupun perusahaan besar berpotensi melakukan manajemen laba. Sebaliknya penelitian ini tidak mendukung Mabrurah, Islahuddin, dan Arfan (2017) yang menyatakan bahwa ukuran perusahaan tidak berpengaruh terhadap earnings management.

\section{Pengaruh Leverage \\ terhadap Earnings Management}

Berdasarkan tabel 10 menunjukkan koefisien regresi positif sebesar 0,293099. Probabilitas menunjukkan nilai yang lebih kecil dari 0,05 yaitu
0,0052. Hal ini berarti tingkat signifikansinya lebih kecil dari $a=5 \%$, sehingga hipotesis ke10 berhasil didukung atau $\mathrm{H}_{0}$ ditolak. Penelitian ini berhasil membuktikan bahwa leverage berpengaruh positif dan signifikan terhadap earnings management. Hal ini menunjukkan bahwa utang perusahaan digunakan bukan untuk kegiatan operasional semata melainkan agar laporan keuangan perusahaan terlihat baik, salah satunya bahwa terdapat ketersediaan aset lancar berupa kas yang nilainya material.

Hasil penelitian ini mendukung penelitian dari Rice (2016) yang menyatakan bahwa Leverage berpengaruh terhadap manajemen laba. Sebaliknya, penelitian ini tidak mendukung penelitian Savitri dan Priantinah (2019) dan Almadara (2017), yang menyatakan bahwa variabel Leverage berpengaruh negatif terhadap manajamen laba. Tingginya Leverage suatu perusahaan yang ditandai dengan tingginya tingkat hutang mengakibatkan manajemen menjadi lebih sulit untuk memprediksi masa depan perusahaan. Kreditor akan melakukan pengawasan yang lebih ketat ketika perusahaan memiliki hutang yang tinggi.

\section{Pengaruh Corporate Social Responsibility terhadap Earnings Management}

Berdasarkan tabel 10 menunjukkan koefisien regresi positif sebesar 0,139166. Probabilitas menunjukkan nilai yang lebih kecil dari 0,05 yaitu 0,0263 . Hal ini berarti bahwa tingkat signifikansinya lebih kecil dari $\alpha=5 \%$, sehingga hipotesis ke-11 berhasil didukung atau $\mathrm{H}_{0}$ ditolak. Penelitian ini menunjukkan variabel corporate social responsibility berpengaruh positif dan signifikan terhadap earnings management.

Hasil penelitian ini mendukung penelitian yang dilakukan oleh Ricardo dan Faisal (2015) yang menemukan hasil corporate social responsibility berpengaruh pada manajemen laba. Disebutkan bahwa biaya politis yang tinggi akan cenderung memberikan peluang untuk melakukan manajemen laba. 
Pengaruh Ukuran Dewan Komisaris terhadap Earnings Management dengan Corporate Social Responsibility sebagai variabel Intervening

Hasil penelitian menunjukkan bahwa ukuran dewan komisaris mempunyai hubungan langsung dengan earnings management serta ukuran dewan komisaris mempunyai hubungan tidak langsung dengan earnings management. Sebab uji parsial variabel ukuran dewan komisaris terhadap variabel corporate social responsibility memiliki signifikansi sebesar 0,3538 sedangkan uji parsial variabel corporate social responsibility terhadap variabel manajemen laba memiliki signifikansi sebesar 0,0263. Dengan demikian dapat disimpulkan variabel corporate social responsibility adalah bukan sebagai mediator diantara variabel ukuran dewan komisaris dengan variabel earnings management. Hal ini dikarenakan oleh faktor lain seperti: independensi, komposisi, kompetensi, dan motivasi dewan direksi. Karena banyak anggota dewan komisaris yang tidak memiliki kompetensi yang dibutuhkan oleh perusahaan sehingga keberadaannya tidak dapat memonitoring manajemen perusahaan secara optimal (Sunarsih, 2017).

\section{Pengaruh Dewan Komisaris Independen terhadap Earnings Management dengan Corporate Social Responsibility sebagai variabel Intervening}

Hasil penelitian menunjukkan bahwa dewan komisarisindependenmempunyaihubunganlangsung dengan earnings management serta dewan komisaris independen mempunyai hubungan tidak langsung dengan earnings management. Sebab arena uji parsial variabel dewan komisaris independen terhadap variabel corporate social responsibility memiliki signifikansi sebesar 0,3941. Sedangkan uji parsial variabel corporate social responsibility terhadap variabel earnings management memiliki signifikansi sebesar 0,0263. Dengan demikian dapat disimpulkan bahwa variabel corporate social responsibility adalah bukan sebagai mediator di antara variabel dewan komisaris independen dengan variabel earnings management. Hal ini dapat dijelaskan bahwa besar kecilnya dewan komisaris bukanlah menjadi faktor penentu utama dari efektivitas pengawasan terhadap manajemen perusahaan. Namun demikian efektivitas mekanisme pengendalian tergantung pada nilai, norma, dan kepercayaan yang diterima dalam suatu organisasi. Selain itu, efektivitas pengawasan juga tergantung pada bagaimana komunikasi, koordinasi, dan pembuatan keputusan (Sunarsih, 2017).

\section{Pengaruh Komite Audit terhadap Earnings Management dengan Corporate Social Responsibility sebagai variabel Intervening}

Hasil penelitian menunjukkan bahwa komite audit mempunyai hubungan langsung dengan earnings management. Komite audit juga mempunyai hubungan tidak langsung dengan earnings management karena uji parsial variabel komite audit terhadap variabel corporate social responsibility memiliki signifikansi sebesar 0,0177. Sedangkan uji parsial variabel corporate social responsibility terhadap variabel manajemen laba memiliki signifikansi sebesar 0,0263. Sehingga dapat disimpulkan bahwa variabel corporate social responsibility merupakan parsial mediator diantara variabel komite audit dengan variabel earnings management menjadi semakin transparan (Sunarsih, 2017).

\section{Pengaruh Ukuran Perusahaan terhadap} Earnings Management dengan Corporate Social Responsibility sebagai variabel Intervening

Hasil penelitian menunjukkan bahwa ukuran perusahaan mempunyai hubungan langsung dengan earnings management dan ukuran perusahaan mempunyai hubungan tidak langsung dengan earnings management. Sebab uji parsial variabel ukuran perusahaan terhadap variabel corporate social responsibility memiliki signifikansi sebesar 0,0030. Sedangkan uji parsial variabel corporate social responsibility terhadap variabel manajemen laba memiliki signifikansi sebesar 0,0263. Dengan demikian dapat disimpulkan variabel corporate social responsibility adalah sebagai parsial mediator di antara variabel ukuran perusahaan dengan variabel earnings management. 


\section{Pengaruh Leverage terhadap Earnings Management dengan Corporate Social Responsibility sebagai variabel Intervening}

Hasil penelitian menunjukkan bahwa leverage mempunyai hubungan langsung dengan earnings management dan leverage mempunyai hubungan tidak langsung dengan earnings management. Karena uji parsial variabel leverage terhadap variabel corporate social responsibility memiliki signifikansi sebesar 0,0219. Sedangkan uji parsial variabel corporate social responsibility terhadap variabel earnings management memiliki signifikansi sebesar 0,0263. Sehingga dapat disimpulkan variabel corporate social responsibility adalah sebagai parsial mediator di antara variabel leverage dengan variabel earnings management.

\section{SIMPULAN}

Pengaruh ukuran dewan komisaris terhadap corporate social responsibility menunjukkan nilai negatif. Penelitian ini berhasil membuktikan bahwa ukuran dewan komisaris berpengaruh negatif namun tidak signifikan terhadap pengungkapan corporate social responsibility. Pengaruh dewan komisaris independen terhadap corporate social responsibility menunjukkan nilai positif. Penelitian ini berhasil membuktikan bahwa komisaris independen berpengaruh positif namun signifikan terhadap corporate social responsibility.

Pengaruh komite audit terhadap corporate social responsibility menunjukkan nilai positif. Penelitian ini berhasil membuktikan bahwa komite audit berpengaruh positif dan signifikan terhadap corporate social responsibility. Pengaruh ukuran perusahaan terhadap corporate social responsibility menunjukkan nilai positif. Penelitian ini berhasil membuktikan bahwa ukuran perusahaan berpengaruh positif dan signifikan terhadap corporate social responsibility. Pengaruh leverage terhadap corporate social responsibility menunjukkan nilai positif. Penelitian ini berhasil menunjukkan bahwa leverage berpangaruh positif dan signifikan terhadap corporate social responsibility.

Pengaruh ukuran dewan komisaris terhadap earnings management menunjukan nilai negatif. Penelitian ini berhasil membuktikan bahwa ukur- an dewan komisaris berpengaruh negatif dan signifikan terhadap earnings management. Pengaruh dewan komisaris independen terhadap earnings management menunjukkan nilai negatif. Penelitian ini berhasil membuktikan bahwa dewan komisaris independen berpengaruh negatif dan signifikan terhadap earnings management. Pengaruh komite audit terhadap earnings management menunjukkan nilai negatif. Penelitian ini berhasil membuktikan bahwa komite audit berpengaruh negatif dan signifikan terhadap earnings management.

Pengaruh ukuran perusahaan terhadap earnings management menunjukkan nilai positif. Penelitian ini menunjukkan bahwa ukuran perusahaan berpengaruh positif dan signifikan terhadap earnings management. Pengaruh leverage terhadap earnings management menunjukkan nilai positif. Penelitian ini berhasil membuktikan bahwa leverage berpengaruh positif dan signifikan terhadap earnings management. Pengaruh corporate social responsibility terhadap earnings management menunjukkan nilai positif. Penelitian ini berhasil membuktikan bahwa corporate social responsibility berpengaruh positif dan signifikan terhadap earnings management.

Pengaruh ukuran dewan komisaris terhadap earnings management dengan corporate social responsibility sebagai variabel intervening. Penelitian ini berhasil membuktikan bahwa corporate social responsibility bukan sebagai mediator antara variabel ukuran dewan komisaris dengan earnings management. Pengaruh dewan komisaris independen terhadap earnings management dengan corporate social responsibility sebagai variabel intervening. Penelitian ini berhasil membuktikan bahwa corporate social responsibility bukan sebagai mediator antara variabel dewan komisaris independen dengan earnings management.

Pengaruh komite audit terhadap earnings management dengan corporate social responsibility sebagai variabel intervening. Penelitian ini berhasil membuktikan bahwa corporate social responsibility sebagai parsial mediator antara variabel komite audit dengan earnings management. Pengaruh ukuran perusahaan terhadap earnings 
management dengan corporate social responsibility sebagai variabel intervening. Penelitian ini berhasil membuktikan bahwa corporate social responsibility sebagai parsial mediator antara ukuran perusahaan dengan earnings management. Pengaruh leverage terhadap earnings management dengan corporate social responsibility sebagai variabel intervening. Penelitian ini berhasil membuktikan bahwa corporate social responsibility sebagai parsial mediator antara variabel leverage dengan earnings management.

\section{PENGHARGAAN}

Saya mengucapkan terima kasih kepada Dr. (HC) Darsono selaku Ketua Yayasan Sasmita Jaya, H. Endang Ruhiyat, S.E., M.M., CSRA., CMA selaku Dekan Fakultas Ekonomi, dan Efriyanti SE, M.Sim, selaku Kaprodi Akuntasi Universitas Pamulang serta rekan rekan dosen lainnya yang telah mendukung terwujudnya penelitian ini

\section{DAFTAR PUSTAKA}

Almadara, H. U. (2017). Pengaruh Leverage Terhadap Manajemen Laba dengan Corporate Governance Sebagai Variabel Moderasi Pada Perusahaan Perbankan yang Terdaftar Di BEI. Skripsi.

Amelia, Winda \& Hernawati, Erna. (2016). Pengaruh Komisaris Independen, Ukuran Perusahaan dan Profitabilitas terhadap Manajemen laba. UPN Veteran: Jakarta.

CSR Indonesia. (2016). Catatan "Global CSR Summit \& Awards 2016.

Elvina, N., Makhdalena, \& Trisnawati, F. (2016). Analisis pengaruh kepemilikan manajerial, kepemilikan institusi, leverage, terhadap pengungkapan corporate social responsibility (Studi empiris pada perusahaan manufaktur yang listing di BEI). JOMFKIP, 3(2), 1-15.

Ghozali, Imam, (2016). Aplikasi Analisis Mulivariate dengan Program SPSS. Semarang: Penerbit Universitas Diponegoro.

Ghozali, Imam, (2013). Aplikasi Analisis dengan Program IBM SPSS 21. Edisi 7. Semarang: Penerbit Universitas Diponegoro.

Ginting, Y. L. (2016). Mekanisme Tata Kelola dan Pengungkapan Tanggung Jawab Sosial Perusahaan. Jurnal Ekonomi dan Manajemen, 13.

Gunawan, Fajar. (2015). Hubungan antara mekanisme corporate governance terhadap pengungkapan corporate social responsibility. Skripsi Universitas Diponegoro.

Gunawan \& Situmorang, E.M. (2016). Pengaruh Dewan Komisaris, Kepemilikan Manajerial dan Komite Audit terhadap Manajemen Laba pada Perusahaan di BEI 2011-2015. Jurnal Ekonomi Manajemen dan Perbankan.

Gunawan,I Ketut, Nyoman Ari Surya Darmawan dan Gusti Ayu Purnawati. (2015).Pengaruh Ukuran Perusahaan, Profitabilitas, dan Leverage terhadap Manajemen Laba pada Perusahaan Manufaktur yang Terdaftar di Bursa Efek Indonesia (BEI). Volume 3. Nomer 1.

Hadi, Nor. (2014). Corporate Social Responsibility. Yogyakarta: Graha Ilmu.

Herawati, H. (2015). Corporate governance, karakteristik perusahaan dan pengungkapan corporate social responsibility, 2(2).

Mabrurah, Laila., Islahuddin, dan Arfan, M. (2017). Pengaruh Ukuran Perusahaan, Asimetri Informasi, Komposisi Dewan Komisaris dan Ukuran Dewan Komisaris terhadap Manajemen Laba Pada Perusahaan Manufaktur Yang Terdaftar di BEI. Jurnal Magister Administrasi Pendidikan: Universitas Syiah Kuala.

Maulidra Hazra. (2015). Pengaruh Struktur kepemilikian saham dan leverage terhadap corporate social reposnsibility (Studi empiris pada perusahaan manufaktur yang isting di BEI 2010-2012. Skripsi Universitas Negri Semarang.

Marlisa,Otty dan Siti Rokhimi Fuadati. (2016). Analisis Faktor Faktor yang Mempengaruhi Manajemen Laba Perusahaan Properti dan Real Estate.Volume 5. Nomer 7.

Munawir. (2010). Analisis Laporan Keuangan Edisi Keempat, Cetakan Kelima Belas. Yogyakarta: Liberty.

Pradana, Andre Virgia. (2017). Pengaruh Good Corporate Governance, Profitabilitas, dan Ukuran Perusahaan terhadap Pengungkapan 
Corporate Social Responsibility (Studi Empiris pada Perusahaan Manufaktur yang terdaftar di BEI Periode Tahun 2013-2015). Skripsi. Surakarta: Universitas Muhammadiyah.

Pradnyani dan Sisdyani. (2015). Pengaruh ukuran perusahaan, profitabilitas, leverage dan ukuran dewan komisaris pada pengungkapan taggung jawab sosial perusahaan.

Prasetya, P dan Gayatri. (2016). Pengaruh Ukuran Perusahaan Terhadap Manajemen Laba Dengan Corporate Governance Sebagai Variabel Intervening, Vol. 14. No. 1.

Rindawati, Meita Wahyu. (2015). Pengaruh Profitabilitas, Ukuran Perusahaan Leverage, dan Kepemilikan Publik terhadap Pengungkapan Corporate Social Responsibility (CSR). Skripsi. Surabaya: Sekolah Tinggi Ilmu Ekonomi Indonesia.

Rofiqkoh, E., \&Priyadi, M. P. (2016). Pengaruh profitabilitas, leverage, dan ukuran perusahaan terhadap pengungkapan tanggung jawab sosial perusahaan. Jurnal Ilmu dan Riset Akuntansi, 5(10), 1-18.

Ricardo, D. M., \& Faisal. (2015). Pengaruh Pengungkapan Corporate Social Responsibility Terhadap Praktik Manajemen Laba. Diponegoro Journal of Accounting, 4, 33-42.

Rice. (2016). "Pengaruh Faktor Keuangan terhadap Manajemen Laba dengan Corporate Governance sebagai Variabel Moderating". Jurnal Wira Ekonomi Mikroskil. Volume 6, Nomor 01, April 2016.

Sari Amelia Chrisnata. (2015). Pengaruh Mekanisme Corporate Governance terhadap Kinerja Perusahaan Pada Sektor Consumer Goods Industry di BEI Periode 2009-2013. Jurnal Ilmiah Mahasiswa Universitas Surabaya.

Savitri, Diana \& Priantinah, Denies. (2019). Pengaruh Leverage Terhadap Manajemen Laba Dengan Corporate Governance Sebagai Variabel Pemoderasi Pada Perusahaan Manufaktur Sektor Aneka Industri Yang Terdaftar di BE 2013-2016. Jurnal Nominal Vol VIII no 2 .

Sugiyono. (2011). Statistik untuk Penelitian. Bandung: Alfabeta.
Sugiyono, (2012). MetodelogiPenelitian Kuantitatif Kulitatif Dan R\&D. Bandung: Alfbeta.

Sugiono. (2014). Metode Penelitian Bisnis. Cetakan Ke 18. Bandung: Alfabeta.

Sugiyono, P. D. (2016). Metode Penelitian Administrasi Dilengkapi dengan Metode R\&D (Edisi 23). Bandung: Alfabeta.

Sukasih, A., \& Sugiyanto, E. (2017). Pengaruh struktur good corporate governance dan kinerja lingkungan terhadap pengungkapan corporate social responsibility (Studi pada perusahaan manufaktur di Bursa Efek Indonesia Periode 2011-2015). Riset Akuntansi dan Keuangan Indonesia.2(2).121-131.

Sumaryono, A., \& Asyik, N. F. (2017). Pengaruh Size, Profitabilitas dan Leverage terhadap Pengungkapan Corporate Social Responsibility. Jurnal Ilmu Dan Riset Akuntansi, $6,1-17$.

Sunarsih. 2017. Pengaruh Manajemen Laba Terhadap Pengungkapan Corporate Social Responsibility (CSR) Dengan Mekanisme Corporate Governance Sebagai Variabel Moderasi Pada Perusahaan Yang Terdaftar di Jakarta Islamic Index (JII). E-journal.uin. Volume 17, Nomor 1. Page: 33-38

Sartono, Agus. (2014). Manajemen Keuangan Teori dan Apikasi. Edisi Keempat. Yogyakarta: BPFE.

Suryani, A., \& Herianti, E. V. A. (2015). Pengaruh Pengungkapan Tanggung Jawab Sosial Perusahaan terhadap Koefisen Respon Laba dan Manajemen Laba. Simposium Nasional Akuntansi XVIII. Medan.

Susilo,M. S., \& Milldawati, T. (2015). Pengaruh good corporate governance terhadap luas pengungkapan corporate social responsibility. Jurnal Ilmu dan Riset Akuntansi, 4(5), 1-16.

Suwardjono, S. (2011). Teori akuntansi perekayasaan pelaporan keuangan (3 ed.). Yogyakarta: BPFE Yogyakarta.

Urip, Sri. (2014). Strategi CSR. Tanggung Jawab Sosial Perusahaan. Tangerang: Penerbit Literati.

Pria Juni Prasetya, Gayatri. (2016). "Pengaruh Ukuran Perusahaan terhadap Manajemen Laba dengan Pengungkapan Corporate Social 
Responsibility sebagai Variabel Intervening". E-Jurnal Akuntansi Universitas Udayana. ISSN : 2303-1018. Volume 14.1 Januari 2016: 511-538.

Putra, K. W. S. (2016). Peran Dewan Komisaris Terhadap Pengungkapan Corporate Social Responsibility Dengan Profitabilitas Sebagai Variabel Moderator. Jurnal Manajemen \& Bisnis. ISSN:1892-8486, 13(1), 28-37.

Wiagustini, Ni Luh Putu. (2010). Dasar-Dasar Manajemen Keuangan. Denpasar: Udayana
University Press.

Wiyuda, A., \& Purnomo, H. (2017). Pengaruh good corporate governance, karakteristik perusahaan terhadap luas pengungkapan corporate social responsibility pada perusahaan terdaftar di BEI. Kompartemen, 15(1), 12-26. Wulandari, S., \& Zulhaimi, H. (2017). Pengaruh Profitabilitas terhadap Corporate Social Responsibility Pada Perusahaan Manufaktur dan Jasa Yanga Terdaftar di BEI. Jurnal Riset Akuntansi dan Keuangan, 2(2), 101-111. 